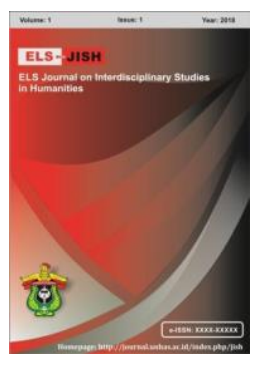

ELS-JISH

ELS Journal on Interdisciplinary Studies on Humanities

Volume 3 Issue 4, 2020

ISSN (print) : 2621-0843

ISSN (online) : 2621-0835

Homepage : http://journal.unhas.ac.id/index.php/jish

\title{
“The Cure" in Margary's The Postmortal: A Vanishing Technological and Transhumanist Mediator Towards an Ageless Existence
}

\author{
Niñoval F. Pacaol ${ }^{*}$ \\ 1'ninoval.pacaol05@gmail.com
}

\begin{abstract}
The 2011 science fiction novel of Drew Magary named The Postmortal drew a world wherein the cure for aging has been scientifically and technologically advanced through gene therapy by the medical practitioner Graham Otto. This paper hinges on the 'vanishing mediator' as a theoretical framework synthesized by Kahambing which runs in four distinct stages for its entire process, namely, to: a.) retroactively trace the intervention, b.) evaluate the intervention, $c$.) identify the mediator, and d.) locate the vanishing point. Applying this to the movement, the methodological structure of the paper is divided into four parts. First, it provides a primary discussion of the social "normal" condition of people in the novel to traceably locate the intervention made by Graham Otto, a doctor, to completely halt the aging process. Second, the researcher presented a technological intervention of gene therapy in the character of Doctor Otto in making a scientific cure for aging. Third, the said intervention is argued to be a vanishing mediator. Finally, it gave a full account of the major implications of a Bostromean transhuman process and its traces in the world at large.
\end{abstract}

Keywords: Aging, Death, Gene Therapy, Immortality, Vanishing Mediator

How to cite: Pacaol, N. (2020). "The Cure" in Margary's The Postmortal: A vanishing technological and transhumanist mediator towards an ageless existence. ELS-Journal on Interdisciplinary Studies in Humanities, 3(4), 560-571. DOI:

https://doi.org/10.34050/elsjish.v3i4.11686

\section{Introduction}

The living illustration of human species as it theoretically emerged (with a significant and high degree of probability) from evolution by natural selection has been indubitably shaped and challenged by its subsisting limitations. On this matter, the most widely held and conventional existential limitations are 1) humans' inability to know future events and all the secrets of the cosmos in general and 2) death. Nevertheless, throughout history, these two major human limitations serve as a complementary component of each other. Man's inability to have a full grip of everything led to his progress during antiquity as he became familiar with the natural world. He utilizes his skills and reasoning character to support him that would later give rise to a vast range of knowledge such as science. In the contemporary century, science aims to solve the

${ }^{1}$ Social Science Unit, Leyte Normal University, Philippines. 
biological riddle of aging that could stop (for at least hundreds or thousands of years) the coming of death.

The scientific advancement since the eighteenth century creates an impetus for scientists and philosophers to envisage the likelihood of conquering and cheating death during the great leap of human civilization in the incoming centuries. Such profound experimental concepts have roots in the umbrella term posthumanism: an expression of what would be an epochal era of human society in which everything is distinctive from the "classical world of man." That is, "the possibilities that beckon the mystery of the human mind to grasp what is more than what it is - this has long been the trajectory that drives man's fate beyond (Kahambing, 2018a: 1)." Specifically, transhumanism, as part of posthumanism's threads, strives for the improvement and ultimate perfection of humanity (with some arguing for the attainment of human immortality). For Bostrom (2005: 4), an Oxford transhumanist philosopher, transhumanists yearn for "responsible use of science, technology, and other rational means we shall eventually manage to become posthuman, beings with vastly greater capacities than present human beings have."

In his 2011 book The Physics of the Future, theoretical physicist Michio Kaku writes that by 2050 it might be possible to slow down the biological process of aging via a variety of therapies such as stem cells, the human body shop, and gene therapy to fix aging genes. In the province of literature and movie industry, voluminous works have been produced deliberating the prospect of immortality or perpetual youthful living in the future. The 2011 science fiction novel of Drew Magary sketched a fictional story (yet quasirealistic) of a world wherein a cure for aging has been developed and created by Doctor Graham Otto through gene therapy. Likewise, the novel presents a dystopian future inhabited by a multitude of human beings who no longer age. However, with the introduction of the cure in the general public, Drew made a pessimistic account for its underlying and direct corollaries in a large scale of the picture: the world is characterized by overpopulation, unending strife, and environmental decline. The Postmortal is a unique and exceptional work that encourages its readers to consider questions concerning morality, aging, genetic engineering, assisted suicide, and others (Gilbert, n.d.). Such literary evaluation can be framed based on the experimental power and capacity of science which is manifestly conceivable in the real condition of the present era.

More to the point, any person who is progressing through the pages of the fictional novel would probably face the inevitable question of the human imagination: would it be possible for the fictitious and postmortal narrative account to become a reality? It also encourages its readers to consider themselves and their actions, with regards to society as a whole, as they follow the life of John Farrell, the main character. An opening note from the year 2093 - "A Note about the Text: From the Department of Containment, United North American Territories" - tells the reader that the entire fictional writing is a compilation of online journal entries of John that covers sixty years of the twenty-first century. The U.S. Department of Containment published John's writings for two foremost rationales, that is: it is one of the most definitive personal records or first-person accounts of end specialization industry and 
unassailable proof that the cure must never again be permitted and legalized. Considering such titillating prologue, John's articles were divided into four parts: 1.) Prohibition: June 2019,2 .) Spread: June 2029, 3.) Saturation: March 2059 , and 4.) Correction: June 2079.

Furthermore, this paper sought to examine and consider the cure invented by Doctor Otto via gene therapy in halting the process of human aging in Magary's The Postmortal novel as an active mechanism in initiating a great change in men's social and living condition of the novel's fictional world. Even though it is certain that other researchers have established already the implications of such probable scientific hypothesis or test (see for example Boyer, 2017; Utt, 2012), nonetheless, the researcher clearly expressed and emphasized that its fundamental effects would be due to the pro tem and transitory existence of the aforesaid technological transhuman process that tends to overthrow the biological limits of human beings inherited from its evolutionary development.

\section{Method}

Throughout the paper, the researcher employed the 'vanishing mediator' as a theoretical framework postulated by Kahambing (2019a). Vanishing mediator is generally taken as a mediating catalyst that permits changes between two exclusive concepts and vanishes after its task is done (Kahambing, 2019a; 2019b). Yet the vanishing point of the mediator does not imply absolute extinction since it is now incorporated in the new structure contrary to the mediating phase (old system/ structure). The role of the mediator is deemed to be active as it makes radical and immense changes in the erstwhile edifice. Operating under the guidance of Kahambing's 'vanishing mediator,' the cure for biological aging invented through gene therapy in Magary's The Postmortal is argued to be a vanishing mediator towards an ageless and eternally young lifetime of humanity as an escape.

For a solicitous examination of the study, Kahambing (2019a) suggested and synthesized a process in methodologically determining the vanishing mediator in which the researcher meticulously used, namely, to: a.) retroactively trace the intervention, b.) evaluate the intervention, c.) identify the mediator, and d.) locate the vanishing point. Following this definite process, the paper runs in four parts. First, it provides a primary discussion of the social "normal" condition of people in the novel to traceably locate the intervention made by Graham Otto to completely halt the aging process. Next, it presents a technological intervention of gene therapy in the character of Doctor Otto in making a scientific cure for aging. Afterward, the said intervention arguably functions as a vanishing mediator. Finally, it gives a full account of the major implications of such a transhuman process and its traces in the world at large.

\section{Discussion}




\subsection{The Classical and Natural Life of Man}

The opening pages of the novel elucidate the living boundaries of humans before the postmortal that results in the instigation of the transhuman revolution. To be exact, the fictional caricature of the novel on the normal mode of the human being can be genuinely and historically traced back to the perilous conditions of our ancestors in the Pleistocene era which makes the human lifespan to evolve to diminutive seven to eight decades. In contrast to the Anthropocene era today (Kahambing, 2019c), the Pleistocene epoch allowed for the moment for man to realize his limited timeframe in the vast fabric of the cosmos. As such, human life-form endeavors to enhance its body functionality for a better way of living (e.g. by getting some vaccinations, drugs) to lengthen his existential years and postpone the coming of death. John Farrell, the protagonist of the story, and many other clients who are seeking for the "cure" presumed that such scientific invention was an antidote and/or answer for death, though it is not: "it was only a cure for aging." With these in mind, the said scientific development towards a transhuman society was just a form of life extension and in becoming a "postmortal" [impermanent immortality (having an indefinite number of ageless years yet death still waits)] not for absolute immortality. The doctor affirmed to John that anyone could still die:

\section{You can still catch a cold. You can still die of AIDS or a heart attack. You can still get cancer. People can still murder you...this is no cure for death, even if everyone is calling it that. It's merely a cure for aging. In fact, if Malthus's theory is right, you certainly will die. It may be a hundred years from now. It may be ten thousand years from now. But it will happen. (Magary, 2011: 18-19).}

Whether the intent and the impelling cause of the people supporting the legalization of the cure is for impermanent or absolute immortality, aging and death seem to be the crucial subjects and great existential nemesis in the novel. In some studies, fear of aging was found to be related to death anxiety (Klammack \& Roff, 1984). Roth (1978) points out that death is a complete representation of all the anxieties of aging that together disturbs older people and so haunts human species since the dawn of civilization to circumvent from such natal and genetic normal-defect. Turner (2004) enumerated three factors which are well-linked to the deliberate and inadvertent struggles to increase life longevity and prolonged man's existence, namely: fear of death, fear of dying, and the desire to maintain good health to accomplish life projects and goals. Fear of death is a substantial element for the pursuit to increase human longevity particularly for the secular community and a group of people who do not hold the idea of the afterlife will reliably fear death and hope to remain alive and involved in human affairs and social linkages. Whereas it is an evolutionary and universal truth that everyone must and will die, fear of dying is often associated with the reluctance of human beings "to experience the pain and suffering that often accompanies the dying process" (Turner, 2004: 122). Maintaining that health is wealth as a foundation to enjoy one's existential needs and wants or dreams, the temptation and interest to halt the dying process, avoiding death, and other related illnesses appears to be relatively high. These aforesaid considerations could be simply approached and summarized by John's own words: "I don't want to die. I'm terrified of death. I 
fear there's nothing beyond it and that this existence is the only one l'll ever possess" (Magary, 2011: 19).

In the context of John's statement, nothing indicates and presumes that death is a metaphysical phenomenon. Thus, death, which could be a result of biological aging, can also be described as a solitary and isolating experience (Feder, 1976). As social animals, interaction and socialization make humanity's existence meaningful. If death is a separation from everything we have, it is the passing of all the things that we cherish (Hinton, 1967). What is more painful and distressing would be the loss of someone's loved one (Gordon, 2000). Hypothesizing the chance to have a cure for aging implies a world shattering breakthrough. In his national statement, the novel's U.S. president accentuated that the cure is a means to have a "very long" (perhaps thousands of years) and "wonderful life" with our loved ones (Magary, 2011: 72). In the heights of biomedicine of the twentieth century, scientists started to strive for the identification of biological data from the human body that could alter the aging process.

\subsection{Creation, Intention, and Scientific Intervention}

Under the model of a (normal) human being, the gamut of all potential and conceivable activities, feelings, experiences, and so on happen to be a mere fraction (see Figure 1). Though we are heading towards progress with the institution of the scientific and industrial revolution of the eighteenth and nineteenth centuries, we are still constricted within our biological nature. And as human society was modernized through different stages of development, similarly, the human becomes keen to improve and reconstruct himself. Bostrom clinches that

Our own current mode of being, therefore, spans but a minute subspace of what is possible or permitted by the physical constraints of the universe... It is not farfetched to suppose that there are parts of this larger space that represent extremely valuable ways of living, relating, feeling, and thinking. (Bostrom, 2005: 5; emphasis added).

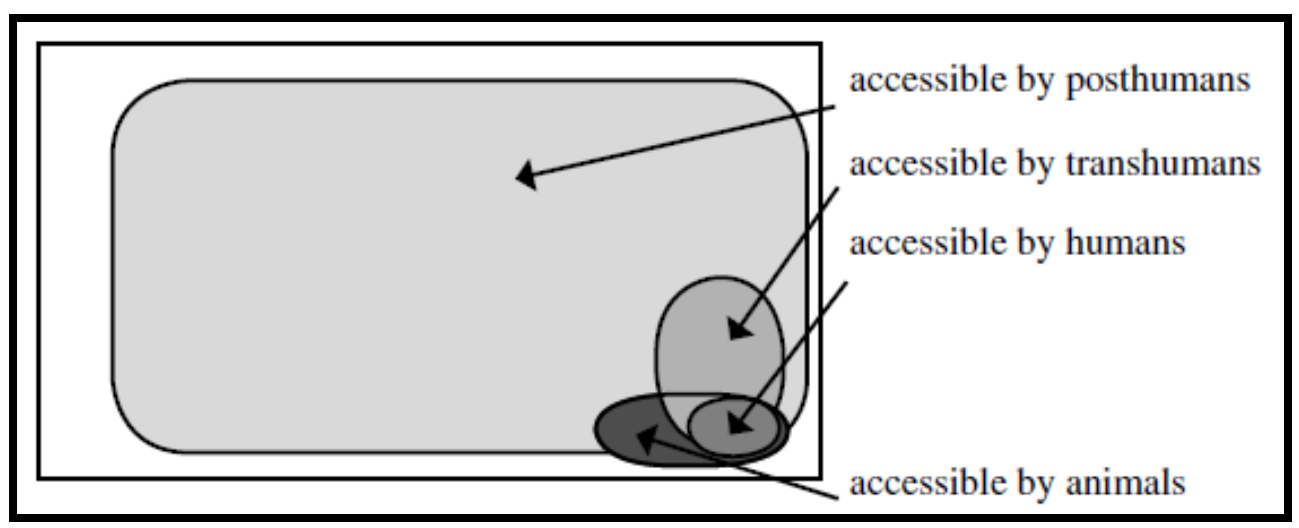

Figure 1. The Space of Possible Modes of Being (Bostrom, 2005)

One of the futuristic fields of study is transhumanism that has its roots in the 1920s and 1930s (Kreowski, 2017). Utilizing science and technology, transhumanists hunt for furtherance and evolution of intelligent human life beyond its current form and limitations. For Bostrom (2005), advancing the 
principles of transhumanism does not connote that it favors posthuman beings over human beings. Instead, as an appropriate interpretation, to prefer and advance the interest of human beings is to realize his ideals in which some of these might be outside the natural mode of his existence but comprehensible within his current existential nature. Moving ahead, determining the future of humanity by way of science's potency, in Magary's The Postmortal, the "cure" fulfilled the hopes of the other half of the world's population to freeze and halt the biological and natural process of aging which elongate the life expectancy from the average seventy years to impermanent immortality. That is, one could expect to live up to a thousand years yet death remains unavoidable. Even so, what the "cure guarantees is that you will never die a natural, peaceful death" (Magary, 2011: 19).

The divisive and radical invention of the "cure" was primarily due to the scientific knowledge of its designer - Doctor Graham Otto. An article written by reporter Mike Dermott recounted the scientific journey of Graham as he was about to discover the genetic information that will change everything. Essentially, it was not the aspiration of Graham to conquer or cheat death in the process. His initial goal was just to "help out the redheads of the world" (Magary, 2011: 55). Through gene therapy, Graham targeted MCR1 (commonly found in chromosome 16), and based on the complete map of the human genome; it is the gene that causes red hair. Graham struggled to solve the central problem of what he called "wasn't the most noble of genetic experiments." Taking away someone's genetically predisposed color, an albino (or colorless) will be the result, adding the preference hair color as problematic. Working on the experiment, fruit flies served as the subjects of the test and altering the proteins found elsewhere in their DNA helix. Categorizing negligence and carelessness as undesirable attributes of a good scientist (The National Academies, 2009), nonetheless, it was an accident and coincidence that it gave rise to the idea of solving the biological conundrum of aging:

\begin{abstract}
.... In the midst of deadening the red protein in that day's batch of flies, he removed an extra protein from the gene as well...When Otto returned the following morning, nothing unusual had occurred. He tried to introduce a new color protein into the flies' DNA, but it again failed. He placed the batch of flies aside and began taking on a new group of test subjects. But then something odd happened to that tainted sample of flies. "They wouldn't die. A fruit fly usually lives for less than two months. And even then, within twenty-four hours or so, you begin seeing a handful of them drop. But none of the flies I injected with the vector dropped. Ever. They just kept flying around." (Magary, 2011: 56; emphasis added).
\end{abstract}

From such a serendipitous error in scientific experiments, it was supposed that biological aging was solved by the transformed genetic proteins. The moment the cure came to be available in the black market, various doctors began to perform operation and injection to those financially capacitated in return for a very high fee. Its technological and methodological procedure is presented in the discourse scenario of John with the doctor he consulted for the "aging cure":

So, what this involves is me taking a sample of your DNA, then finding and altering-or, more precisely, deactivating - a specific gene in your 
DNA, and then reintroducing it into your body through what's known as a vector, or a carrier. In this case, that means a virus. So I'm going to take some blood from you today, isolate the gene, change it, create the vector virus, and then inject that vector back into your system at three distinct points: your inner thigh, your upper arm, and your neck. That's two weeks from now. And then we're done. After you go home, the virus will replicate the new gene code throughout your system. Within six months, it will be present in all your tissue, and the aging of your body will be permanently frozen where it is. (Magary, 2011: 18; emphasis added).

Among Cave's (2012) four paths to immortality [staying alive, resurrection narrative, soul, and legacy], staying alive impeccably reflects and fits the fictional categorization of the novel about human enhancement program. Similarly, despite his dissimilar classifications of the three pathways, Brown (2017) shared with Cave's first assertion that staying alive or survival of the body is the basic conduit in achieving immortality. To stay young and healthy is the very nature of these existential narratives. Structurally, the next section, Graham's gene therapy's cure for aging as a form of technological transhumanist movement functions as a vanishing mediator towards ageless years of one's existence.

\subsection{Technological Transhumanist Trend of Gene Therapy's Cure for Biological Aging as a Vanishing Mediator}

The dream and tale for/of eternal youth and never-ending life are as old as the history of human civilization and literature. The biblical story of the Garden of Eden and Epic of Gilgamesh are just some of its ancient examples. Some argued that the attainment of physical immortality is a matter of magic, but in contemporary usage, magic is synonymously referred to as "science." Science paradoxically provided the possibility for impossible fantasies that would have been branded as magical as elixirs before (Kahambing, 2019d). Whether such disciplinal perspective is objective or subjective in terms, it is scholarly explained that scientists are triggered to overcome the biological limits of ours such as aging - not as a purposeful and systematized attempt but by the progressive trend of scientific knowledge inherited from positivism and neopositivism (Niiniluoto et al., 2004; Rossi, 1988).

Meanwhile, the transhumanism movement believes positively on the process of "gradual transformation of the human being into an enhanced creature, physically and mentally superior" (Bonifati, 2017: 158) via the application of all the advances of modern science (Livingstone, 2015). Highlighting such a futuristic fate of humanity, then it logically follows that transhumanist in its technological approach would serve as intermediation between the classical and normal condition of man towards a much more liberated and less biologically restricted human species. In the sight of a theoretical language, Kahambing (2019a: 477) proposed that a particular aspect of the human would possibly disappear in "the innovative impetus of current technological transhumanist trends." Among others, this intermediation also means that it would soon disappear the point where the old phase has been replaced by the other, thus, the concept is no longer required and vanishes from the picture. 


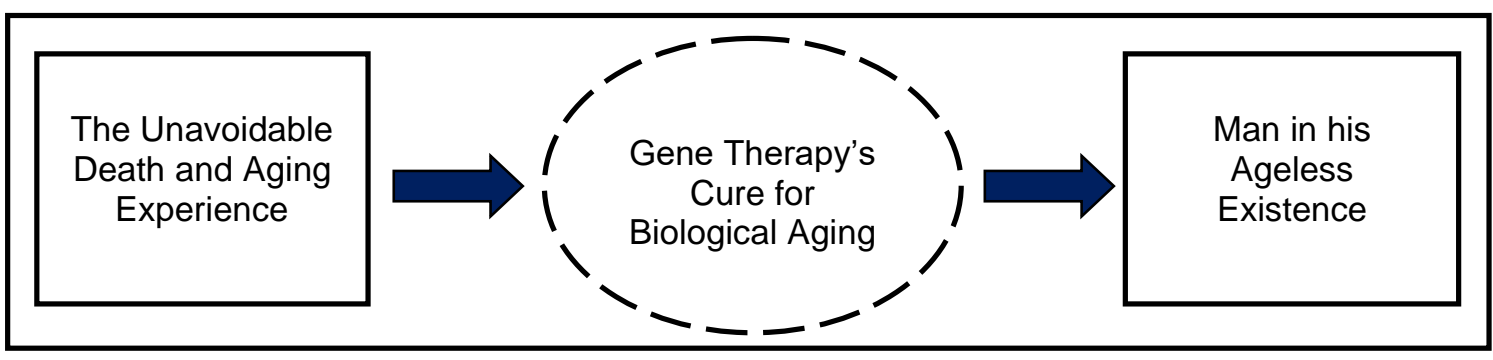

Figure 2. The Basic Schema of Gene Therapy's Cure for Biological Aging as Vanishing Mediator

Utilizing a similar framework in Magary's The Postmortal, the gene therapy's cure for biological aging invented by Doctor Otto functioned as a vanishing mediator towards an ageless existence of humanity in the novel (see Figure 2). It was methodologically stressed that a vanishing mediator is an intermediary between two conflicting and diverging ideas and normally used in historical phases (Kahambing, 2018b). To theoretically establish that the aforesaid technological trend in Magary's fictional world is a vanishing catalyst, a well-researched description could help. Sherkow, Zettler \& Greely (2018: 789) in an attempt to devise a concrete and clear-cut definition of 'gene therapy' claimed that such genetic treatment is "the intentional, expected permanent, and specific alteration of the DNA sequence of the cellular genome, for a clinical purpose" (emphasis added). Following this line of explanation, it can be logically deduced that the moment that John, his friend Chan and other human being received the injection and/or the cure for aging, they will never be the same anymore to their versions before therapeutic care. Simultaneously, therapeutic injection is no longer needed; successively, what someone can do is to "enjoy the rest of your life" (Magary, 2011: 37).

Given such a theoretical statement, one could infer that once a mediator exists between two exclusively different phases it should be an active rather than a passive conduit. The act of vanishing of gene therapy's cure for biological aging, conversely, does not denote complete extinction because it became part in the new phase (Kahambing, 2019a; 2019b). The traces of the said technological transhuman process can be seen through the lens of the novel's narrative. This postmortal scenario of the world characterized by ageless living with an effort to escape death acts as the new phase and segment of human society.

\subsection{In the Pursuit of Immortality, Cheating Death, and its Apparent Traces in the World}

When a new scientific theory and idea is presented into the public square and confronts the social norms of the population, it sometimes ends with the division of the larger society. The history of science witnessed some of its controversies starting from Copernican and Darwinian views on the solar system and diversity of life, respectively. But, how about in the prevailing century? What ideologies and movement (not necessarily within the province of science) have the power to surprise and astonish us? The transhumanism movement is included in the lists with the scientific human enhancement 
program that can be powered primarily by electronic and robotic devices, drugs, medical devices, regenerative medicine, and gene therapy (Bonifati, 2017).

Gene therapy directed the attainment of prolonging life's existence in The Postmortal. But the novel also presented the case of those against transhumanism and life extension groups. The strong opposition of the pope, some extremist groups and even Doctor Otto (the pioneer for the discovery of the cure) himself, the U.S. President secured a three-year ban for the cure but later on altered his decree and approved for its legalization which attracted millions of people and left a significant reminder concerning its possible social corollaries:

And that reality is coming, hurtling toward us faster and faster every day now. I cannot tell you when it will come-perhaps long after l've left office. But it will come. And the question we must all ask ourselves is, are we ready for that reality? I banned this cure three years ago because I wanted us to have as much time as possible to be ready when that day comes, to be prepared for all the responsibilities this cure demands of us. (Magary, 2011: 73; emphasis added).

The debate in the fictional and real setting focused on "sociotechnical" assemblages. We would realize that the discourse on transhumanism is "not simply over allegedly good or evil technologies and, instead, it is about how technologies function in a particular social order" (Lilley, 2013: 6). In the section "Saturation," almost everyone now received the cure and so it would be an infinite generation. The imaginative and optimistic dreams of cure-seeking clients for immortality happened not to correspond after some years of global application. From 2029 and onwards, the world is now characterized by depression and desperation (Utt, 2012). It seems to suggest that the forethought of Doctor Otto back in the year when he discovered the cure was utterly right: "we still don't know what future effects this cure will have" (Magary, 2011: 59).

Talking about death through a philosophical and ontological principle from Heidegger (1962), the knowledge of one's impending death is what completes man's existence. With the removal of this driving force in the postmortal society, The Postmortal characters tend to live meaningless lives: "We see John's life progress towards having no purpose as he quits his job, refuses to marry his true love, and decides not to be in his son's life" (Boyer, 2017: 46). Nietzsche's (2001) declaration that 'God is Dead' indicates the shift from faith towards rationalism as society becomes scientifically advanced. John questions most of the aspects of human living including career, family, marriage, and religion. This could be a liberating start for some, yet Nietzsche himself acknowledged that the abolition of long-established morality particularly from religions signals the advent of nihilistic society. This was stressed by the viciousness and sordidness of the newly established religion - the Church of Man - which denies the monotheistic belief on a transcendent Big Being: "The Church of Man is a nondenominational faith that promotes the worship of Man (and Woman!) on earth... The Church of Man believes that God and Man are one and the same" (Magary, 2011: 132). In this case, men are the killers of God. The fictional portrayal of the decline of religious influence on the concept of death is 
tentatively convincing and possible in our world. The vast ideas of today's technology to fulfill yesterday's imaginations might cause for modern religions and institutions to become vulnerable to it (Edman, 2019).

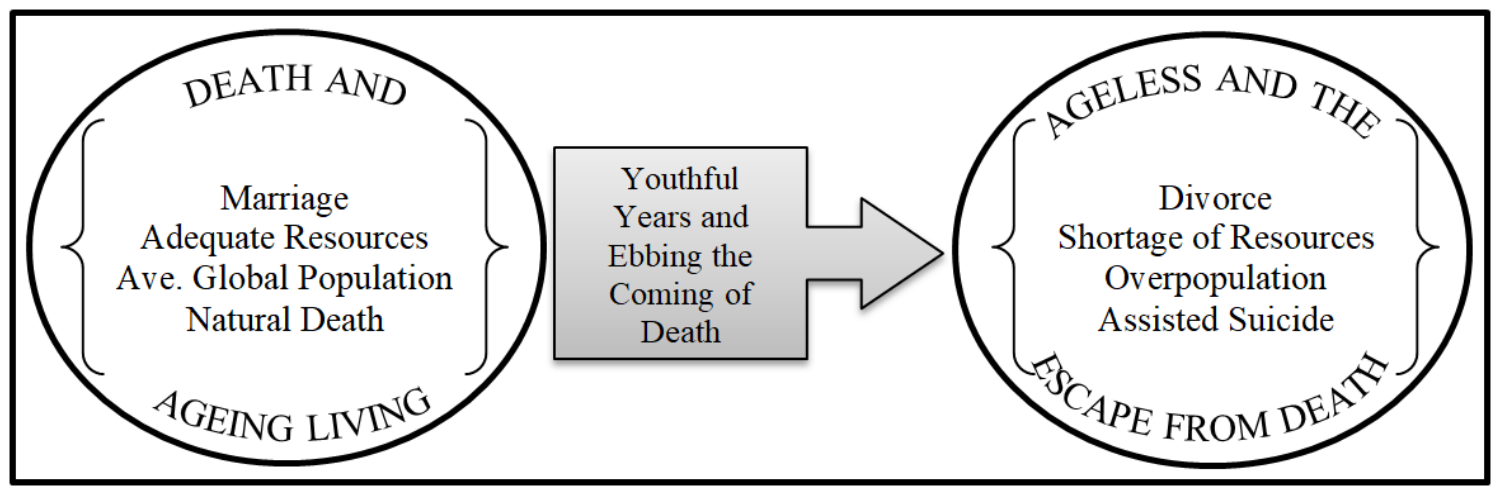

Figure 3. The Novel's Depiction of Global Scenario after the Vanishing Intervention of Otto's Cure for Biological Aging via Gene Therapy

The tragic and meaningless life of the protagonist gives the impression that "society's constructed status quo, like Death and religion, may constrict humanity, but it is necessary" (Boyer, 2017: 49). On top of the personal and private biographic life of John, the world, as a whole, is in the state of decline and out of control (see Figure 3). Such are the traces of the technological intervention of gene's therapy cure for aging pioneered by Doctor Otto: China nuked its cities as a result of overpopulation; Russia aggressively secured resource for the country; shortage of living spaces; unavailability of social security and health benefits for American citizens; the increasing number of divorce given that people were living much longer and the 'death till us part' promise no longer holds and has grown outdated; assisted suicide is legally accessible for those who had received the cure and no longer wished to live; and pillaging and murdering are globally apparent. One could describe the world as an existent example of hell (see for example Huxley, as cited in Kahambing, 2019e).

\section{Conclusion}

The entire study was theoretically approached using Kahambing's synthesis of the vanishing mediator concerning the technological transhumanist intervention of gene therapy performed by Doctor Otto in Magary's novel The Postmortal. Doctor Otto accidentally and later on scientifically discovered the cure for biological aging that momentously brought a transforming influence. Its therapeutic success was systematically and philosophically aligned with the ideology of the transhumanism movement that seeks for all-aspects improvement of the human being to completely depose the existential and biological limitations of men. Magary's dystopian world outlined the likeliness of a damaging reality in the future. Nevertheless, the researcher is not committed to defending either side of the debate on the sociotechnical consequences of transhumanism movement in its pursuit of human immortality. Rather, the paper moderately offers how gene therapy's mediating existence acts as a transitory bridge via the lens of a fictional and historical language and narrative. 


\section{Acknowledgments}

The researcher would like to extend his sincerest gratitude to Professor Jan Gresil Kahambing of Leyte Normal University for his astounding work in proofreading, careful and critical comments and preparing this article for the possible publication.

\section{References}

Bonifati, N. (2017). Toward post- human: The dream of never- ending life. In Jacobsen, M.H. (Ed), Postmortal society: Towards a sociology of immortality. New York, NY: Routledge.

Bostrom, N. (2005). Transhumanist values. In Adams, F. (Ed), Ethical Issues for the Twenty-First Century. Charlottesville: Philosophical Documentation Center Press.

Boyer, J. (2017). What a time to be alive: The philosophical underpinnings of Heidegger and Nietzsche in The Postmortal. The Mall, 1(10), 45-50.

Brown, G. (2017). The future of death and the four pathways to immortality. In Jacobsen, M.H. (Ed.), Postmortal society: Towards a sociology of immortality. New York, NY: Routledge.

Cave, S. (2012). Immortality. New York, United States: Crown Publishers.

Edman, T. B. (2019). Transhumanism and singularity: A comparative analysis of a radical perspective in contemporary works. Gaziantep University Journal of Social Sciences, 18(1), 39-49.

Feder, S. (1976). Attitudes of patients with advanced malignancy. In E.S. Shneidman (Ed.), Death: Current perspectives. Palo Alto, CA: Mayfield.

Gilbert, C. (n.d.). The Postmortal: First year and common reading resource guide. Retrieved from https://www.penguin.com/static/pdf/academic/ Postmortal_TG.pdf

Gordon, R. (2000). Dying and creating: A search for meaning. London: Karnac.

Heidegger, M. (1962). Being and time (J. Macquarrie \& E. Robinson, Trans.). Malden, MA: Blackwell.

Hinton, J. (1967). The physical and mental distress of the dying. Quarterly Journal of Medicine, 32, 1-21.

Kahambing, J.G. (2018a). Without Sex: An Appraisal of Žižek's Posthumanism. International Journal of Žižek Studies, 12(2), 1-16.

Kahambing, J.G. (2018b). Diaspora as Vanishing Mediator: Emancipation of Identity for the Mamanuas of Basey, Samar. In Galang-Pereña, F., Ampil, R., Gonzales, E., \& Lazaro-Zamora, N. (Eds.), Philippines and Asian Studies: Expositions, Explorations, and Expectations (pp. 183-200). Rizal: Word Prints Publishing Services, Inc.

Kahambing, J.G. (2019a). Developing the vanishing mediator as theoretical framework: Synthesis and application. The Journal of International Social Research, 12(64), 470-479. doi: http://dx.doi.org/10.17719/jisr.2019.3368 
Kahambing, J.G. (2019b). Theorizing mamanuan diaspora: From vanishing mediator to performative indigeneity. Rupkatha Journal on Interdisciplinary Studies in Humanities, 11(2), 1-15.

Kahambing, J.G. (2019c). Living the Anthropocene: From the 'End of Nature' to 'Ethical Prospects.' Eubios Journal of Asian and International Bioethics, 29(4), 145-149.

Kahambing, J.G. (2019d). Bargaining with Positivism: Science's nexus to philosophy. Eubios Journal of Asian and International Bioethics, 29(3), 9598.

Kahambing, J.G. (2019e). The ethical nihilism of hedonistic posthuman sex. Eubios Journal of Asian and International Bioethics, 29(6), 203-207.

Kaku, M. (2020). The physics of the future. United States: Doubleday.

Klemmack, D.L. \& Roff, L.L. (1984). Fear of personal aging and subjective wellbeing in later life. Journal of Gerontology, 39(6), 756-758.

Kreowski, H.J. (2017). Transhumanism and nanotechnology-Will old myths come true? In G.D. Crnkovic (Ed), IS4SI 2017 Summit Digitalisation for a Sustainable Society, Gothenburg, Sweden: MPDI. Retrieved from https://www.mdpi.com/2504-3900/1/3/243/pdf

Lilley, S.J. (2013). Transhumanism and society: The social debate over human enhancement. New York: Springer.

Livingstone, D. (2015). Transhumanism: The history of a dangerous idea. S.I.: Sabilillah Publications.

Magary, D. (2011). The Postmortal [Digital copy]. USA: Penguin Books.

Nietzsche, F. (2001). The Gay Science. New York, USA: Cambridge University Press.

Rossi, P. (1988). Storia della scienza moderna e contemporanea. Turin: UTET.

Roth, N. (1978). Fear of death in the Aging. American Journal of Paychotherapy, 32(4), 552-560.

Sherkow, J.S., Zettler, P.J. \& Greely, H.T. (2018). Is it 'gene therapy'? Journal of Law and the Biosciences, 5(3), 786-793. doi:10.1093/jlb/lsy020

The National Academies. (2009). On being a scientist. USA: The National Academies Press.

Turner, L. (2004). Life extension research: Health, illness, and death. Health Care Analysis, 12(2), 117-129.

Utt, M. (2012). [Review of the book The Postmortal by D. Magary]. Summer, 19(3), 20-22.

Wolenski, J. (2004). The history of epistemology. In Niiniluoto, I., Sintonen, M., \& Wolenski, J. (Eds), Handbook of Epistemology. Dordrecht: Kluwer Academic Publishers. 